\title{
Antecedents of Public Trust in Government During the COVID-19 Pandemic in Indonesia: Mediation of Perceived Religious Values
}

\author{
Dadanga Hartanto ${ }^{1}$ \\ Universitas Muhammadiyah Sumatera Utara, Medan, Indonesia \\ Agussani Agussani \\ Universitas Muhammadiyah Sumatera Utara, Medan, Indonesia \\ Juhriyansyah Dalle \\ Universitas Lambung Mangkurat, Banjarmasin, Indonesia
}

\begin{abstract}
Drawing from social cognitive theory, the current study investigated the direct and indirect relationship of public interaction with government officials on SNS (Social Network Sites), perceived government response on COVID-19, and perceived e-governance effectiveness with the overall public trust in government via an underlying mechanism of the perceived religious value. Using a quantitative field survey at local administration levels, the primary data of 478 individuals were collected from two cities in Indonesia and was then analyzed using SmartPls3. Results revealed positive associations among the study variables. The results also supported the mediatory role of the perceived religious value between the association of interaction with government officials on SNS, perceived government response on COVID-19, perceived e-governance effectiveness with overall public trust in government. Key policy insights regarding the use of e-governance channels via religious networks to enhance public trust are presented in the cultural context of a developing country. This study brings valuable insights into the public trust in government during COVID-19.
\end{abstract}

Keywords: perceived government response on Covid-19, perceived egovernance effectiveness, overall public trust in government, perceived religious value, social cognitive theory.

Covid-19 brought many challenges all over the globe (Abel et al., 2020). To control and decrease the number of cases, the governments of many developed and developing nations, including the United States, Germany, India, and Indonesia, have faced many challenges (BodrudDoza et al., 2020). Numerous countries imposed lockdowns of varying degrees (Mansoor, 2021a), and sectors and industries, including education, tourism, hospitality, transportation, and entertainment, to cease or limit their activities (Gates, 2020; Mansoor, 2021a). To deal with uncertainties and disastrous situations, government bodies all over the globe tried to devise policies and actions to ensure the safety and well-being of the people to enhance their trust level in government (Gultom et al., 2020).

\footnotetext{
${ }^{1}$ Corresponding Author: Lecturer at the Department of Public Administration at Universitas Muhammadiyah Sumatera Utara. E-Mail: dadanghartanto@umsu.ac.id
} 
To achieve these objectives, governments utilized various methods like providing timely responses, interacting through social networking sites (SNS) and e-governance channels, and involving religious scholars to help combat the pandemic by enhancing the citizens' confidence in government initiatives (Liang et al., 2020). Despite worldwide usage of religious motivation during the pandemic, most Covid-19 related research has ignored this aspect (Aliyyah et al., 2020). To bridge this knowledge gap, the study integrated religious values, e-governance, and SNS interaction.

Communication has been considered a meaningful way to decrease uncertainty and anxiety levels among people (Royo-Vela \& McBee, 2020). Hence, communication of timely and accurate information by the government officials using Social Networking Sites (SNS) with the public during natural hazards and crises may help maintain public trust in government (Mansoor, 2021b). Notably, during the current pandemic, the government officials of many countries actively communicated with their public via SNS to keep them updated, resulting in a sense of security among them (Wong et al., 2020).

Another vital antecedent leading to government trust is perceived government response to Covid-19. In this connection, many governments designed and utilized digital platforms (Shammi et al., 2020), and health facilities were provided to maintain citizens' trust in the government (Pabbajah et al., 2020). Many countries introduced Digital Tracking and Tracing System (DDTS) for Covid-19 to inform, update the public with the latest situations. This resulted in gaining the substantial trust of citizens in government entities. Additionally, e-governance can play an essential role in gaining public trust and reaching the masses on a timely basis. The literature shows that government officials interacting through SNS (Starke et al., 2020) and perceived e-governance effectiveness (Mansoor, 2021a) positively influence overall public trust. However, to the best of the author's knowledge, no research has examined the direct or indirect impacts of government response on Covid-19 on the overall public trust in government which the current study explores.

Very few studies have covered the religious point of view related to the pandemic. Still, fewer have focused on using religious values by government officials to address safety and wellbeing issues during the pandemic. Additionally, religious values' role in gaining and maintaining citizens' trust in uncertain and crisis circumstances has not been explored in previous literature related to public trust, e-governance, or Covid-19 (Sueca et al., 2021). Therefore, to bridge this existing gap in the literature, the current study examined the mediatory role of perceived religious value between the association of interaction with government officials on SNS, Perceived egovernance effectiveness, and government response Covid-19 with overall public trust in government.

Indonesia has one of the world's largest social media markets, with more than 199 million users in 2020 (Akrim et al., 2021; Atmojo \& Nugroho, 2020). Indonesia is a Muslim majority country where religion plays a vital role in all life practices; along with Islam, other religions such as Buddhism, Christianity, and Hinduism are freely practiced in Indonesia (Mietzner, 2020). Religious scholars worked along with government officials by forming bodies like the International Committee of the Red Cross (ICRC) and the Muhammadiyah Covid-19 Combat Centre (MCCC) to control the outspread of Covid-19 and used SNS to motivate and educate the public (Pabbajah et al., 2020). These measures demonstrate the responsive nature of government and religious scholars, reflecting the importance of studying the impact of religion in building citizens' trust in government during the pandemic.

The current study was based on social capital theory, which emphasizes the importance of institutions working together in harmony (Mudwari et al., 2021). This study shows that the interactions of public bodies on SNS, government and religious bodies' timely response during 
natural hazards together help build social capital resulting in public trust in government. Thus, grounded in social capital theory, the current study aims to achieve the following objectives,

- To study the antecedents of overall public trust in government, including interactions with government officials on SNS, perceived government response on COVID-19, and perceived effectiveness of e-governance;

- To examine the impact of perceived religious value on citizens' trust in government; and

- To investigate the mediation of perceived religious value (the interaction with government officials on SNS, perceived government response on COVID-19, and perceived effectiveness of e-governance) with overall public trust in government.

\section{Literature Review and Theoretical Foundation}

This study's theoretical foundation follows social capital theory, demonstrating the importance of coordination among different government institutions (Crucke \& Slabbinck, 2021). Communication barriers must not exist between government officials and the public so that people feel connected and trust the decisions made at the government level (Ruswanti et al., 2020). Moreover, the interactions of the government officials during crises and the efficient use of egovernance channels can result in higher public trust (Beshi \& Kaur, 2020; Mansoor, 2021a; Wasike, 2017). Government official interactions with the public on SNS, e-governance and their linkages with public trust in local governments, and the perceived religious value can help integrate numerous bodies to work together to create social capital.

\section{Hypothesis Development}

\section{Interactions with Government Officials on SNS, Perceived Government Response to Covid- 19, Perceived E-governance Effectiveness and Overall Public Trust in Government}

Various administrative bodies have incorporated SNS to disseminate valuable policy information to the public (Sadeghi et al., 2018). Arshad and Khurram (2020) asserted that the interaction of government officials on SNS with the public about critical situations and public policies results in a higher level of trust. Moreover, research shows the effectiveness and connectedness of the people with a government official on various social networking sites, i.e., following the political parties' social media pages, posting or retweeting political officials' statements, among others (Yamamori, 2019). Similarly, policymakers' and politicians' tweets, posts, shares, and uploading of informative content on SNS may help develop and maintain public trust in government (Sadeghi et al., 2018). These associations are further explained with the help of social capital theory, which posits that the interaction among various individuals and institutions builds social capital, resulting in public trust in government. Hence, based on the above arguments, literature support and social capital theory it is hypothesized that;

H1a: Interactions with government officials on SNS are positively associated with the overall public trust in government.

Perceived government response on Covid-19 represents the prompt and timely response of the government during the pandemic (Mansoor, 2021b) that helped control the pandemic (Pabbajah et al., 2020). Those citizens who felt confident in the government measures and actions while 
fighting with the Covid-19 possess greater trust in the government (Pabbajah et al., 2020). Likewise, a decrease in the number of cases and death rates represents the effectiveness of various governments' timely and accurate measures to curb the spread of the virus in various regions of the world (Paredes et al., 2021). Researchers also reported the differential level of people's responses during the pandemic in different regions (Evans \& Hargittai, 2020). Such differential levels mean that different governments had to deal with their people differently to gain and maintain their trust level (Rahiem \& Rahim, 2020). Hence, based on the social capital theory, perceived government response on Covid-19 plays an important role in creating a social capital based on integrating various tiers of government to enhance public trust in government. Thus, it is hypothesized that.

H1b: Perceived government response on Covid-19 is positively associated with the overall public trust in government.

Researchers have articulated ethical and legal concerns regarding the government's utilizing individuals' data through smartphones and other digital apps to monitor death rates and the number of infected people during the pandemic (Wirtz et al., 2020). Nonetheless, many have demonstrated the effectiveness of modern digital technologies by government officials to disseminate important information and updates regarding the pandemic (Fetzer et al., 2020; Hale et al., 2020; Mansoor, 2021a). Prior literature indicates the effectiveness of governments' concerns and initiatives to monitor, control and manage natural disasters and crises using digital technologies and channels (Myeong et al., 2014). Moreover, the integration of e-governance via record maintenance, compliance with rules, and active response to control uncertain situations help sustain public trust in local governments (Purwanto et al., 2020). Hence based on the above arguments and social capital theory, the following hypothesis is posited.

H1c: Perceived e-governance effectiveness is positively associated with the overall public trust in government.

\section{Interactions with Government Officials on SNS, Perceived Government Response to Covid- 19, Perceived E-governance Effectiveness and Perceived Religious Value (PRV)}

Perception of value is a fundamental aspect of religion, enriched and enhanced due to meaningful engagement (Kuru, 2009). Literature shows that interactions on SNS using religious content in the right way can act influentially to guide people (Yasuda, 2020). Government officials typically share Quranic verses and Hadees, notes from the bible, and other Holy books on SNS according to the target audience's religion to inspire people to act in a certain way (Baazeem, 2020). Though many governments banned major religious gatherings and other large public gatherings to control the situation and limit the spread of the pandemic (Luczak \& Kalbag, 2018), these actions further reflect government and religious scholars' concern for their people. Hence, individuals with firm religious beliefs might rate government officials highly and associate religion with conveying essential messages and depicting a higher level of trust (Mouritsen, 2006). Therefore, based on literature support and arguments, the following hypothesis is posited: 
H2a: Interactions with government officials on SNS are positively associated with a perceived religious value $(P R V)$.

In uncertain times, religion provides hope to people, especially during the current pandemic where millions of people lost their loved ones, jobs, and businesses. Religion seems to play a vital role in strengthening people's belief that they can beat the virus (DeFranza et al., 2020). Although very little research has paid attention to how government officials can use religious values to enhance good governance, the few studies conducted in Muslim majority countries found that religion plays a central role in policies and law-making (Islam \& Siddika, 2020). Additionally, countries like Saudi Arabia, Indonesia, Pakistan, Malaysia, and Iran require that supreme government authorities follow religious teachings to make policies and government decisions due to the Muslim majority context. Therefore, Muslim government representatives around the world were found to be quoting Hadees, a collection of sacred sayings of The Prophet (P.B.U.H), in response to the current pandemic to encourage people to stay at home, avoid religious gatherings, and unnecessarily go out to make the government regulations more effective (Mietzner, 2020). Similar patterns with varying intensity and procedures can also be witnessed in other countries with non-Muslim majorities for their specific religious values in a particular context to support government actions, policies, decisions to combat the Covid-19 situation. Thus, perceived government response for Covid-19 may have a similar association with perceived religious values in a different cultural context. Therefore, based on literature support and factual argument, the following hypothesis is posited:

H2b: Perceived government response to Covid-19 is positively associated with the perceived religious value $(P R V)$.

The churches and mosques in multiple countries collaborate online with government officials to enlighten religious guidelines (Kuru, 2009). This collaboration ensures cost-effective and convenient ways of communicating and reaching citizens (Mouritsen, 2006). E-governance has also been linked to increasing transparency and poverty reduction and reducing corruption in underdeveloped countries (Bhuiyan, 2011). At the same time, perceived religious values have been linked with improved mental well-being and emotional attachment (Baazeem, 2020). Research also advocates that e-governance has been linked with an efficient way of reaching masses on multiple platforms and bridging gaps for an interactive response. When religious values are added to these interactions, people take more interest in such communications (Baazeem, 2020). Therefore, the following hypothesis is posited:

H2c: Perceived E-Governance Effectiveness is positively associated with the perceived religious value $(P R V)$.

\section{Mediation of Perceived Religious Value (PRV) between Antecedents and Overall Public Trust in Government}

Religion for decades has been taken as a symbol of peace and humanity and a source to settle a dispute among nations and regions; hence, it can play a significant role in developing and enhancing people's trust in the government (Sawatsuk et al., 2018). Moreover, in Muslim majority countries, a strong association is present regarding their political leaders' religious affiliations and Shariah laws (Obid \& Naysary, 2016). Likewise, Muslim societies strongly followed their religious 
scholars and Muslim leaders regarding the precautions to be taken during the Covid-19 pandemic displaying a higher level of trust (DeFranza et al., 2020). Therefore, to be more influential on religious grounds, all-important policies need enforcement through government officials who make sure that Shariah laws (Islamic guidelines for law and enforcement) are enforced and practiced within the country (Sayogo, 2018). A similar situation can be witnessed in countries with a Christian majority, Hinduism majority, or Buddhist majority population regarding specific religious laws enforcement as religious values are considered an important political tool to win public trust in various parts of the world. The perceived religious value expected to be positively linked with overall public trust in government, thus the following hypothesis is posited:

\section{H3: Perceived religious value (PRV) is positively associated with the Overall Public Trust in Government.}

It is ubiquitous in some Muslim countries to support religious, political parties, as the people presume they can better safeguard their religious interests (Mouritsen, 2006). Literature also reveals that when government officials join religious scholars to disseminate critical messages and persuade them to follow the rules and regulations, citizens trust such officials more and follow the same rules and regulations (Sayogo, 2018). This shows the utmost significance of religious leaders in bringing peace, harmony, and stability to a society (Ahmadi, 2021). Therefore, based on the social capital theory, the trust and value created by religious beliefs further enrich public trust in local government, providing support for the conceptualization of mediation of perceived religious values between the association of interaction with government officials on SNS and overall public trust in government. Thus, the following hypothesis is posited:

H4a: Perceived religious value (PRV) mediates the relationship between interactions with government officials on SNS and the overall public trust in government.

Covid-19 took many precious lives. Concerned with public health, many government officials decided that human remains should be buried without observing religious rituals, like Italy, Germany, and Spain, which were hard hit during the virus (Bhuvana \& Vasantha, 2020). Later, some countries handed these duties to the families to practice religious rituals (Khemani, 2020). Many concerns led government officials to consider religious values while formulating policies in response to COVID-19 (DeFranza et al., 2020). However, there is a scarcity of research on the link of perceived religious value with public trust, and specifically, studies exploring the mediated mechanism of perceived religious values are scarce in current literature related to public trust and governance. This research borrowed the social capital theory's conceptualization that perceived government response to Covid-19 and public trust in local government was mediated by social capital created by perceived religious values. Therefore, to bridge this gap in the literature and based on the above theoretically rooted argument, the following hypothesis is posited:

H4b: Perceived religious value (PRV) mediates the association between perceived government response on Covid-19 and the overall public trust in government.

Religion and government are said to be successful when safeguarding the public's fundamental rights and providing them with justice and necessary facilities (Pabbajah et al., 2020). E-governance deals with the application of modern technologies, i.e., smartphones, laptops, and tablets (Susanto et al., 2020). Many governments all over the globe have used these technological 
appliances and various channels to deal with the crises raised during the Covid-19 pandemic (Bhuvana \& Vasantha, 2020). The literature also shows that while adopting modern technologies, governments faced many obstacles, particularly in remote and less developed areas where low literacy rates (Bhuvana \& Vasantha, 2020). Still, majorities have accepted these adoptions positively. Thus, based on the social capital theory, this study conceptualizes that these religious values mediate public trust created by effective e-governance as these values create social capital using belief systems to enrich the public trust in local government. Therefore, to bridge this gap in the literature and follow the social capital theory, which advocates the integration of systems, policies, and institutional engagement to increase overall trust in services (Baazeem, 2020), the following hypothesis is posited:

H4c: Perceived religious value (PRV) mediates the association between perceived E-Governance Effectiveness and the overall public trust in government.

Based on literature review and theoretical foundation, the theoretical framework of the study is given on figure 1 .

\section{Figure 1}

The Theoretical Framework of the Study

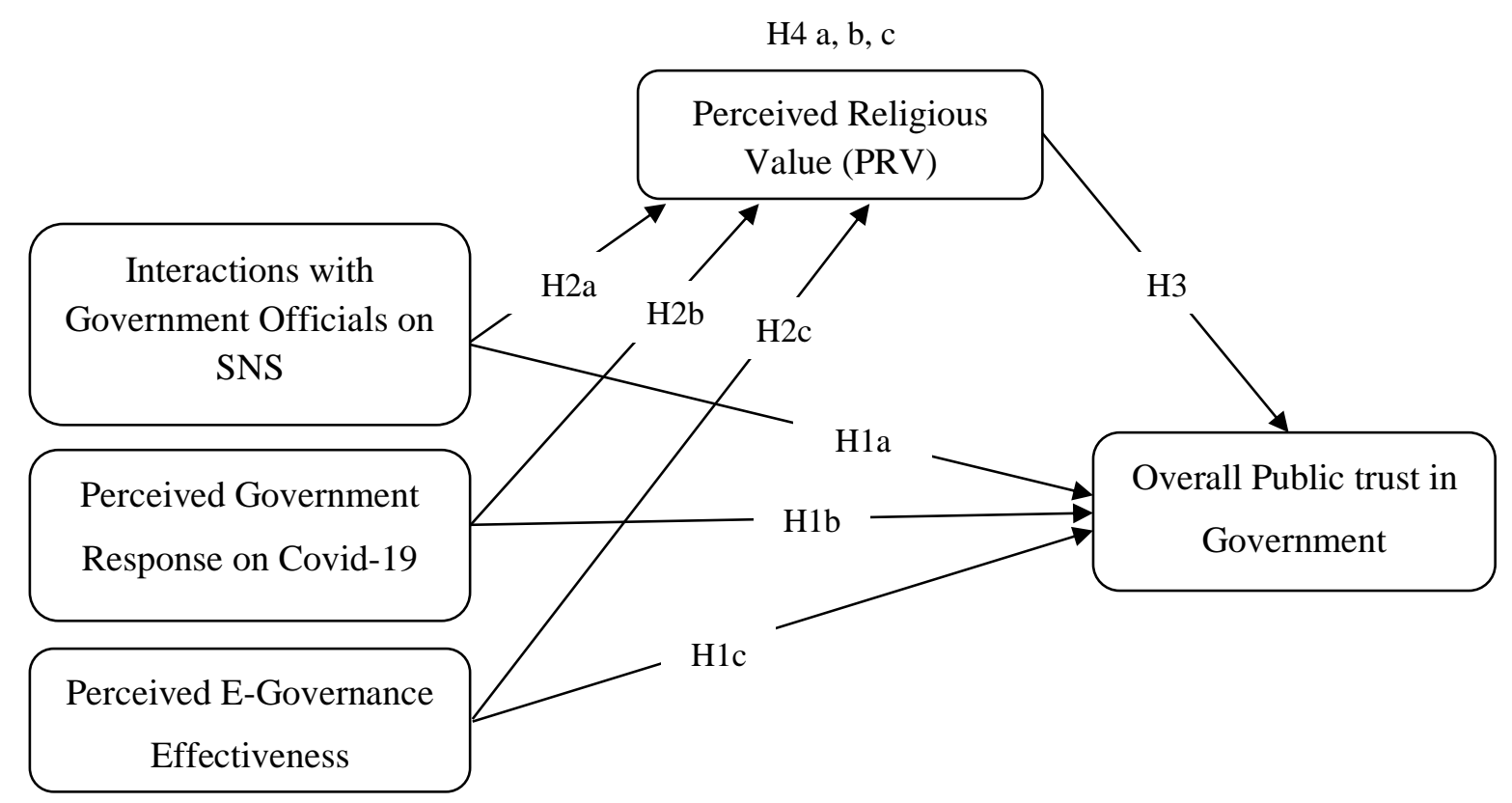

\section{Methodology}

This study applied a quantitative field survey to collect data and examine the proposed associations. Data were collected from citizens of Medan city (North Sumatera Province) and Banjarmasin city (South Kalimantan Province), Indonesia. Although a longitudinal survey is recommended to measure the construct of public trust and its antecedents, a longitudinal study was impossible due to the sudden uncertain and unpredictable emergence of the Covid-19 (Beshi \& Kaur, 2020; Purwanto et al., 2020). 


\section{Sample}

A convenience random sampling collected primary data from different lowest administrative units and public locations in both cities where most educated people lived. The respondents were approached randomly and requested to participate in the study voluntarily. We explained to them the reason for conducting the survey. Also, they were insured about the privacy of their responses. After making sure that all the respondents could understand the language of the survey, they were handed a questionnaire. The survey was prepared in English based on the understanding that Indonesian can better read and English as it is taught in all Indonesian educational institutions from the basic levels. Hence those who could read and understand the survey language were requested to participate, ensuring the selection of respondents appropriate for the current study. Therefore, the initially developed survey with good, reported reliability was adopted used in this research.

\section{Survey Instrument}

The survey had two parts. The first collected demographic items, including gender, age, education level, income level, and political affiliation. The second asked for responses to 47 statements. A 3-item scale adapted from Starke et al. (2020) was measured the interaction with government officials on SNS. Perceived government response to Covid-19 (PGRC) was measured using a 12-item scale (Conway et al., 2020). To measure the perceived e-governance's effectiveness, a 12-item scale adapted from Beshi and Kaur (2020) To measure perceived religious values, a 15-item scale adapted from Huber and Huber (2012) was used. Finally, overall public trust in government was measured with a 5-item scale adapted from Park and Blenkinsopp (2011). A 5-point Likert scale ranging from strongly disagree to strongly agree was used to assess the responses. All the adopted scales had reported reliability of more than the acceptable level of 0.70. See Table 1.

\section{Response Rate}

A total of 560 questionnaires were distributed: 270 in Banjarmasin City and 290 in Medan City. The data collection through online and process took approximately eight weeks, from $10^{\text {th }}$ February 10, 2021, to March 15, 2021. Of the 560 samples sent questionnaires, 427 questionnaires were filled, representing a response rate of about $76.6 \%$. After a detailed and careful screening, 23 incomplete responses were excluded from further analysis. The remaining 404 questionnaires were included for analysis, generating an effective response rate of about $74.1 \%$.

\section{Data Analysis and Results}

A test was performed to check the impact of demographic variables on the dependent construct. The results revealed a significant impact of respondents' age and educational qualification on the dependent variable. Therefore, both age and education were controlled for further analysis. SmartPLS3 was used to analyze the results. Moreover, structural and measurement models were assessed to the proposed hypotheses. 


\section{Respondents Characteristics}

The demographic characteristics of the respondents showed that most (61.9\%) were males and $38.1 \%$ were females. Concerning age, $56.4 \%$ were from the age bracket of $20-30$ years, $32.3 \%$ were $31-40$ years old, and $11.3 \%$ of respondents were above 50 years of age. 59\% of the respondents were graduates, $21.5 \%$ were undergraduates, and $19.5 \%$ were highly qualified postgraduates. Of the respondents, $31.3 \%$ belonged to the low-income category, $47.2 \%$ were middle class, and $21.5 \%$ were upper-middle and upper class.

\section{Analysis of Measurement Model}

A measurement model was used to determine the psychometric properties of the study constructs. Confirmatory factor analysis was performed using SmartPLS3 software. Before assessing the model fit indices, Cronbach's $\alpha$, composite reliability (CR), Composite Reliability (CR), and Average Variance Extracted (AVE) were assessed (Henseler et al., 2009; Mansoor \& Paul, 2021). The results in Table 1 show that the CA of all the study constructs was above the recommended value, i.e., 0.70. For perceived e-governance effectiveness, two itemsPEGE4 and PEGE10, and for perceived religious value, three items, PRV5, PRV9, and PRV11, had factor loadings less than the recommended value of 0.70 ; hence, they were excluded from the further analysis (Hair et al., 2010). For all remaining constructs, AVE values were above 0.50, and CR values were more than 0.70 . Thus, construct reliability and $\mathrm{CR}$ were established. Moreover, Table 2 presents all the factor loadings of the study constructs.

\section{Table 1}

Factor Loadings, Reliability, and Validity

\begin{tabular}{|c|c|c|c|c|c|c|c|c|}
\hline \multirow[t]{2}{*}{ Construct/indicators } & & \multicolumn{4}{|c|}{ Factor Loadings } & \multirow[t]{2}{*}{ AVE } & \multirow[t]{2}{*}{$\mathrm{CR}$} & \multirow[t]{2}{*}{$\begin{array}{c}\text { Cronbach's } \\
\alpha \\
\end{array}$} \\
\hline & 1 & 2 & 3 & 4 & 5 & & & \\
\hline Interaction with & & & & & & & & \\
\hline $\begin{array}{l}\text { Government Officials on } \\
\text { SNS }\end{array}$ & & & & & & 0.553 & 0.788 & 0.797 \\
\hline IWGOSNS1 & 0.728 & & & & & & & \\
\hline IWGOSNS2 & 0.733 & & & & & & & \\
\hline IWGOSNS3 & 0.770 & & & & & & & \\
\hline $\begin{array}{l}\text { Perceived Government } \\
\text { Response to COVID-19 }\end{array}$ & & & & & & 0.555 & 0.908 & 0.812 \\
\hline PGROC1 & & 0.704 & & & & & & \\
\hline PGROC2 & & 0.751 & & & & & & \\
\hline PGROC3 & & 0.762 & & & & & & \\
\hline PGROC4 & & 0.715 & & & & & & \\
\hline PGROC5 & & 0.758 & & & & & & \\
\hline PGROC6 & & 0.723 & & & & & & \\
\hline PGROC7 & & 0.769 & & & & & & \\
\hline PGROC8 & & 0.763 & & & & & & \\
\hline PGROC9 & & 0.786 & & & & & & \\
\hline
\end{tabular}



PGROC10
0.775
PGROC11
0.751
PGROC12
0.692

Perceived E-Governance

Effectiveness

PEGE1

PEGE2

PEGE3

PEGE5

PEGE6

PEGE7

PEGE8

PEGE9

PEGE11

PEGE12

Perceived Religious

Value

PRV1

PRV2

PRV3

PRV4

PRV6

PRV7

PRV8

PRV10

PRV12

PRV13

PRV14

PRV15

Overall Public Trust in

Government

OPTIG1

OPTIG2

OPTIG3

OPTIG4

OPTIG5 $\begin{array}{lll}0.539 & 0.903 & 0.830\end{array}$

0.793

0.629

0.734

0.727

0.790

0.720

0.715

0.753

0.800

0.794 $\begin{array}{lll}0.523 & 0.897 & 0.787\end{array}$

0.788

0.787

0.728

0.629

0.717

0.713

0.688

0.721

0.674

0.634

0.717

0.790

Note. C.R., composite reliability; AVE, average variance extracted.

Moreover, to establish the construct's discriminant validity, the Heterotrait-Monotrait (HTM.) ratio was assessed (Henseler et al., 2015; Noor et al., 2021). Table 2 below shows; all values were less than 0.9 for the entire model establishing the discriminant validity of all the study constructs. 
Table 2

Heterotrait-Monotrait Ratio

\begin{tabular}{lccccccc}
\hline Construct & Mean & STD & 1 & 2 & 3 & 4 & 5 \\
\hline IWGOSNS & 4.02 & 0.55 & $\mathbf{0 . 7 4 3}$ & & & & \\
PGROC & 3.97 & 0.72 & 0.461 & $\mathbf{0 . 7 4 5}$ & & & \\
PEGE & 4.11 & 0.56 & 0.341 & 0.528 & $\mathbf{0 . 7 3 4}$ & & \\
PRV & 3.84 & 0.67 & 0.434 & 0.531 & 0.523 & $\mathbf{0 . 7 2 3}$ & \\
OPTIG & 3.90 & 0.77 & 0.352 & 0.402 & 0.365 & 0.419 & $\mathbf{0 . 7 1 9}$ \\
\hline
\end{tabular}

Note. The square roots of AVEs of the constructs are shown in bold in diagonal. IWGOSNS= Interaction with Government Officials on SNS; PGROC $=$ Perceived Government Response on COVID-19; PEGE= Perceived E-Governance Effectiveness; PRV= Perceived Religious Value; OPTIG= Overall Public Trust in Government

Figure 2 below shows the full measurement model.

\section{Figure 2}

\section{Full Measurement Model}

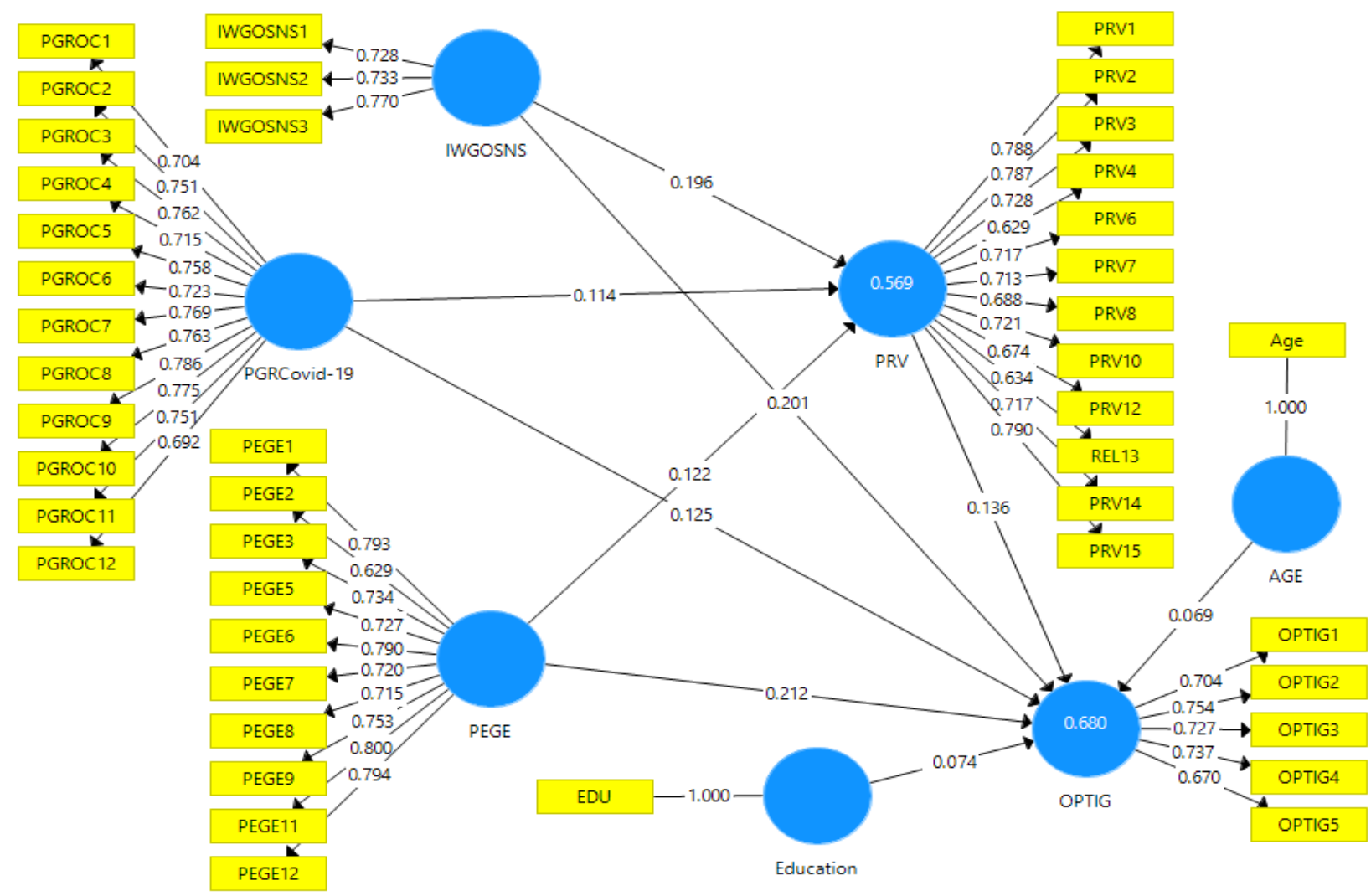

\section{Analysis of the Structural Model}

The structural models were used to assess the hypothesized relationships, for which the bootstrapping technique in SmartPLS3 with 500 sub-samples was applied. The results were confirmed via the ß-coefficient p-value and t-value (Shmueli et al., 2019). In addition, the Coefficient of Determination $\left(\mathrm{R}^{2}\right)$ was calculated to determine the overall fitness of the conceptual 
framework. The $\mathrm{R}^{2}$ values show a $68 \%$ variance in overall public trust due to all direct and mediating variables. The $\mathrm{R}^{2}$ for perceived religious value was $56.9 \%$, showing a good fit for the model.

\section{Direct Hypothesis}

The results presented in Table 3 show the following: interaction with government officials on SNS ( $\beta=.201 * *, t=5.786)$, perceived government response on Covid-19 ( $\left.\beta=.125^{* * *}, \mathrm{t}=3.807\right)$, perceived e-governance effectiveness $(B=.212 * * *, \mathrm{t}=5.807)$ was positively and significantly related to overall public trust in government. Likewise, results also revealed the following: interaction with government officials on SNS $\left(\beta=.196^{* * *}, t=4.989\right)$, perceived government response on Covid-19 ( $(=.114 * *, t=3.356)$, perceived e-governance effectiveness $(\beta=.122 * * *$, $\mathrm{t}=3.626)$ was positively and significantly related to the perceived religious value. Whereas perceived religious value was positively and significantly related to overall public trust in government $\left(\beta=.136^{* * *}, \mathrm{t}=3.983\right)$. Therefore, hypotheses $\mathrm{H} 1 \mathrm{a}, \mathrm{b}, \mathrm{c}, \mathrm{H} 2 \mathrm{a}, \mathrm{b}, \mathrm{c}$, and $\mathrm{H} 3$ were fully supported (See Table 3 below).

\section{Mediation Hypothesis}

As shown in Table 3, the mediation hypotheses $\left(\mathrm{H}_{4 a}, \mathrm{H}_{4 b}\right.$, and $\left.\mathrm{H}_{4 c}\right)$ were supported. An indirect and positive association of interaction with government officials on SNS in the presence of perceived religious value as a mediator was found with overall public trust in government ( $B$ $=.102 * *, \mathrm{t}=2.839, \mathrm{p}<0.012)$. Also, a positive and an indirect association of perceived government response on Covid-19 in the presence of perceived religious value as a mediator was found with overall public trust in government $\left(\beta=.141^{* * *}, \mathrm{t}=4.013, \mathrm{p}<0.000\right)$. Likewise, a positive and an indirect relationship of perceived e-governance effectiveness in the presence of perceived religious value as a mediator was found with overall public trust in government $\left(B=.123^{* * *}, \mathrm{t}=3.712, \mathrm{p}<\right.$ $0.000)$.

Table 3

Hypothesis Testing Results

\begin{tabular}{llcccc}
\hline & Hypotheses & Std. Beta & $t$-Value & $p$-values & Findings \\
\hline $\mathrm{H}_{1 \mathrm{a}}$ & IWGOSNS $\rightarrow$ OPTIG & 0.201 & 5.786 & 0.000 & Supported \\
$\mathrm{H}_{1 \mathrm{~b}}$ & PGROC $\rightarrow$ OPTIG & 0.125 & 3.807 & 0.000 & Supported \\
$\mathrm{H}_{1 \mathrm{c}}$ & PEGE $\rightarrow$ OPTIG & 0.212 & 5.807 & 0.000 & Supported \\
$\mathrm{H}_{2 \mathrm{a}}$ & IWGOSNS $\rightarrow$ PRV & 0.196 & 4.989 & 0.000 & Supported \\
$\mathrm{H}_{2 \mathrm{~b}}$ & PGROC $\rightarrow$ PRV & 0.114 & 3.356 & 0.003 & Supported \\
$\mathrm{H}_{2 \mathrm{c}}$ & PEGE $\rightarrow$ PRV & 0.122 & 3.626 & 0.000 & Supported \\
$\mathrm{H}_{3}$ & PRV $\rightarrow$ OPTIG & 0.136 & 3.983 & 0.000 & Supported \\
$\mathrm{H}_{4 \mathrm{a}}$ & IWGOSNS $\rightarrow$ PRV $\rightarrow$ OPTIG & 0.102 & 2.839 & 0.012 & Supported \\
$\mathrm{H}_{4 \mathrm{~b}}$ & PGROC $\rightarrow$ PRV $\rightarrow$ OPTIG & 0.141 & 4.013 & 0.000 & Supported \\
$\mathrm{H}_{4 \mathrm{c}}$ & PEGE $\rightarrow$ PRV $\rightarrow$ OPTIG & 0.123 & 3.712 & 0.000 & Supported \\
\hline
\end{tabular}


Figure 3 below shows the full structural model with t-statistics values of the hypothesized paths.

\section{Figure 3}

\section{Full Structural Model}

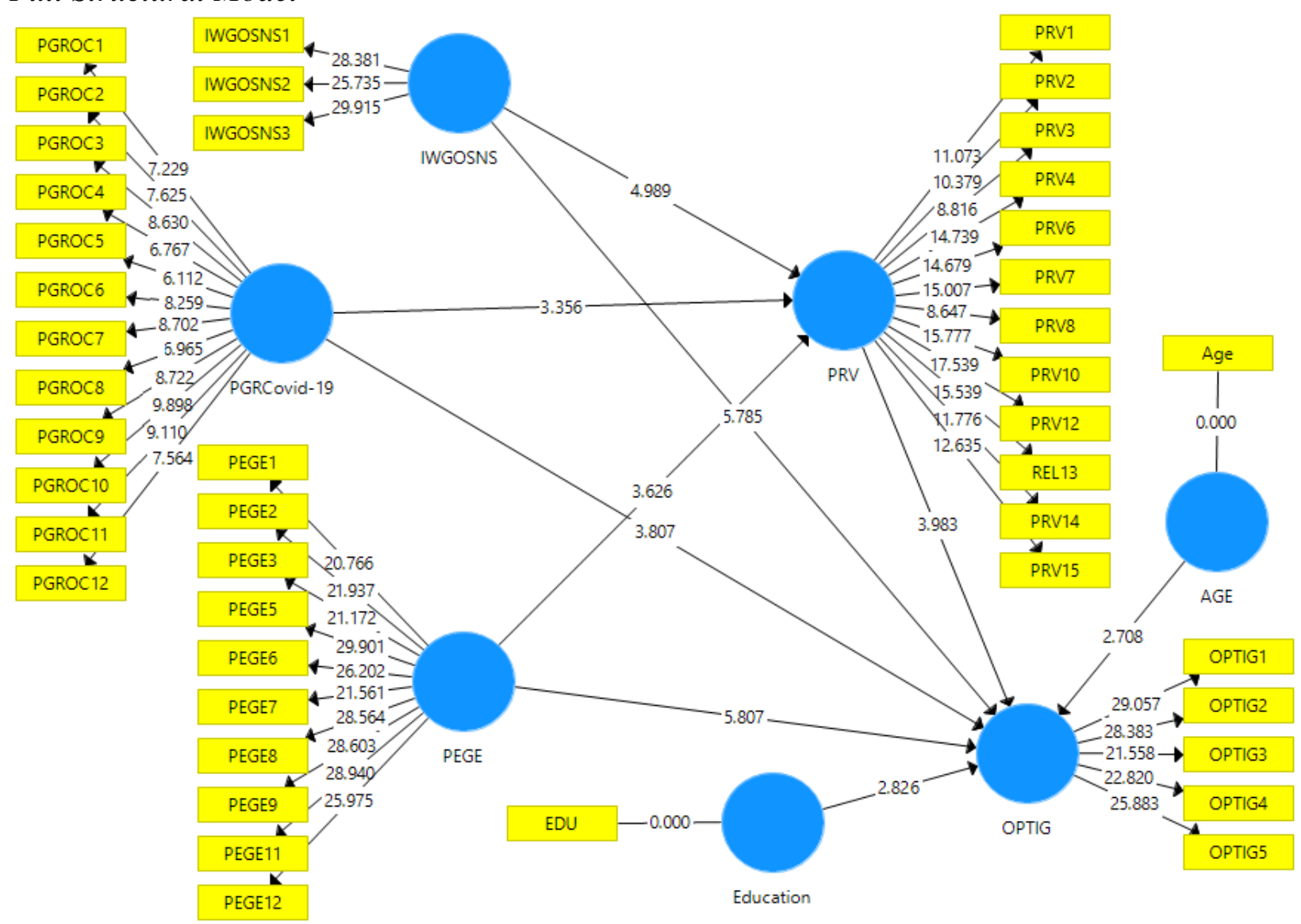

\section{Discussion}

During the Covid-19 pandemic, many nations had to take urgent and critical decisions that resulted in varied nature and level of trust among the public in government. Grounded in the social capital theory, the current study investigated the antecedents of public confidence in the government and the mediating role of perceived religious value, which advances the existing body of knowledge. The results revealed that interactions with government officials on SNS had a significant impact on trust in government. These findings are in line with the results of Ruswanti et al. (2020), which reported that the government has been active over social media interacting with the public for the campaign and daily communication, including sharing information on the crisis and emergency feedback on policies.

Moreover, the results showed that the citizens liked the timely response and role their government officials and institution played in controlling the virus, resulting in a higher level of trust among them. In addition, the Indonesian government passed the HQ law to prevent the virus, which is declared for public health emergencies like food contamination, nuclear radiation emission, or plague (Mietzner, 2020). Additionally, the Indonesian government also launched a 
monetary fund to distribute loans among the needy, provide healthcare and medical staff resources, and enforce strict lockdowns to close public places (Olivia et al., 2020).

Moreover, during the pandemic, an effective and timely response of the government was witnessed that was not limited to spreading knowledge about the pandemic but also included stringent measures to follow SOPs and the provision of medical facilities (Olivia et al., 2020). These all measures helped governments to develop and restore trust among the masses. In addition, a positive association of perceived e-governance effectiveness with overall public trust in government was found. This finding reflects that when e-governance channels are used to communicate and guide the people regarding critical matters quickly, the people express more trust in the government (Purwanto et al., 2020). Moreover, because the Indonesian government specifically introduced and used various disaster management websites (i.e., www.covid19.go.id) and helplines to get in touch with the public and provide them all necessary medical and other facilities, which resulted in a higher level of public trust in their government.

Finally, a significant mediating role of perceived religious value between Interactions with government officials on SNS and public trust in government. (Seifert \& Kwon, 2019). Moreover, the mediating role of perceived religious value between perceived government response on Covid19 and public trust in government was also supported. To support the government's cause of combating the virus and protecting the people from the deadly disease, most religious leaders came to the forefront to spread awareness (Akrim et al., 2021). Moreover, to stop the spread of the pandemic, they made important announcements regarding limiting religious activities and the cancellation of many religious gatherings (Rahiem \& Rahim, 2020).

Similarly, the mediating role of perceived religious value between perceived e-governance effectiveness and public trust in government was also significant. This shows that using religious values can increase e-governance effectiveness, enhancing public trust in government. In many religiously democratic countries, i.e., Indonesia, where Islam is the state religion, most important decisions are made in light of Islamic teachings and principles. Likewise, people mostly believe in their religious leaders and obey their teachings; hence religion plays an essential role in building trust among the public.

\section{Theoretical Implications}

This research has multiple theoretical implications.

1. First, the current study utilized social capital theory to examine the impact of various factors in developing and maintaining public trust in government. These factors include constructs such as public trust, e-governance effectiveness, and government policies, and performance-based research.

2. The second significant theoretical advance of this research is studying the role of perceived religious value in the Covid-19 pandemic context, which has been previously explored and examined by a few researchers and can bring valuable insights for future researchers.

3. The third significant advance of the current study is examining the impact of government interactions on SNS with establishing and maintaining trust among the citizens on government decisions and actions. Moreover, the current study is incremental in the body of literature, studying the role of government interactions on SNS during the current pandemic. This will further provide an avenue for future researchers to explore the role of active participation and direct communication of government bodies on social media and 
other digital channels to build trust and a sense of satisfaction among the public (Dalle et al., 2020).

4. The fourth theoretical contribution of this study includes the empirical testing of perceived government response on Covid-19 with perceived religious value and public trust. This contribution further opened several avenues for researchers to explore other underlying mechanisms that can transmit the effectiveness of the government's prompt and timely response in building trust among citizens.

5. Finally, this study contributed to theories related to e-governance by integrating it under social capital theory to play a vital role in creating public trust.

\section{Practical Implications}

The current study also has several important implications for policymakers, politicians, public administrators, and government officials.

1. First, the importance of the perceived religious value in attaining and maintaining public trust in government, as shown by the current study results, shows that religious democracies should accelerate the incorporation of religious laws and guidelines to help control and end this pandemic (DeFranza et al., 2020).

2. Second, based on the fact that peoples' faith motivates and encourages them to act in a specific manner and persuade others, religious scholars can help government officials guide and persuade people to follow SOPs during pandemic times to save their own lives and the lives of others.

3. Third, based on the study findings related to an enhanced public trust in the government in response to their increasing interactions with the government officials on SNS, such interactions and communications should be accelerated to make the public happy and satisfied with the government decisions.

4. Fourth, this study also found that perceived government response on Covid-19 can significantly impact public trust in government. Therefore, policymakers should prioritize citizens' safety and health by responding to their concerns and health observations.

5. Fifth, this study suggests that perceived e-governance effectiveness positively influences citizens' trust in the government; hence, governments all over the globe should use various channels of ICT to gain public trust and establish a strong economy.

6. Finally, using technology and social media and their positive role in creating public trust in government is another central policy insight for policymakers. Moreover, the current study made an advance to the existing body of literature by proposing that governments can use religious teachings and e-governance channels to create a positive difference in people's perception of government.

\section{Limitations and Future Directions}

In addition to many strengths, this study has limitations that need to be addressed. This study was conducted in Indonesia, a Muslim majority developing country, an Islamic context was studied as perceived religious values. Future studies can generalize this research's findings and focus on other religions and their role in promoting public trust in government policies in other countries with a non-Muslim majority context. Future studies in Indonesia may take an inclusive sample where people from all major religions should provide more concrete and generalizable 
evidence. Another limitation was that this study focused on the public point of view, and hence the data were obtained from the general public. Future studies can incorporate government officials' points of view and their challenges in fighting the virus. Future studies can also focus on the effectiveness of use; task forces created to fight the virus, including public and government representatives. Moreover, the limitation of cross-sectional research design can be overcome with longitudinal or time-series research design in the future for better causality and predictability in the future. Future scholars may also conduct a cross-country comparative study to compare two or three different countries, each managed by a different religious majority population and government. A very interesting comparative study could be conducted for India, Indonesia, the Philippines, and Thailand ss Indonesia is a Muslim majority population, the Philippines is a Christian majority population, and Thailand is a Buddhist majority population. At the same time, India is a Hindu majority population. Thus, such a study may bring globally generalizable insights for the governments, leaders, public administrators, and policymakers.

\section{Conclusion}

Keeping the uncertain situations faced by all the nations all over the globe due to the sudden outburst of the Covid-19, the current study has been conducted to address a very sensitive and critical issue linked with public trust in the governments (Hale et al., 2020). Hence, to answer the crucial questions related to the influence of public interaction with government officials on SNS (Social Network Sites), perceived government response on COVID-19, and perceived egovernance effectiveness on the overall public trust in government, a theoretical model of the study was established based on the social capital theory. Moreover, this study used a quantitative field survey at local administration levels among the citizens of Medan and Banjarmasin City, Indonesia. Data were analyzed using SmartPLS3, applying measurement and structural models. Results revealed the positive associations of public interaction with government officials on SNS (Social Network Sites), perceived government response on COVID-19, and perceived e-governance effectiveness with the overall public trust in government. The results also supported the mediatory role of the perceived religious value between the association of interaction with government officials on SNS, perceived government response on COVID-19, perceived e-governance effectiveness with overall public trust in government. Besides, the mediatory role of perceived religion between the above associations was empirically tested. These findings suggest the utmost importance of communication between government officials and the public using digital technologies and SNS. Likewise, results show the importance of prompt and effective response of the government during crises to win the public trust (Mansoor, 2021a) to achieve long-term prosperity. Furthermore, key policy insights regarding the use of e-governance channels via religious networks to enhance public trust are discussed in detail.

\section{References}

Abel, B., Gray, D. M., Anik, I., \& Bhuiyan Suraiya, A. (2020). Literature review of the economics of COVID-19 (No. 13411). IZA Discussion paper.

Ahmadi, A. (2021). The traces of oppression and trauma to ethnic minorities in Indonesia who experienced rape on the 12 May 1998 tragedy: A review of literature. Journal of Ethnic and Cultural Studies, 8(2), 126-144. 
Akrim, A., Rudianto, R., \& Adhani, A. (2021). Interactive effects of Stoicism and religious coping on psychological distress, fatigue and intercultural communication: Muslim health workers in Bali. Journal of Ethnic and Cultural Studies, 8(4), 214-237.

Aliyyah, R. R., Rachmadtullah, R., Samsudin, A., Syaodih, E., Nurtanto, M., \& Tambunan, A. R. S. (2020). The perceptions of primary school teachers of online learning during the COVID19 pandemic period: A case study in Indonesia. Journal of Ethnic and Cultural Studies, $7(2), 90-109$.

Arshad, S., \& Khurram, S. (2020). Can government's presence on social media stimulate citizens' online political participation? Investigating the influence of transparency, trust, and responsiveness. Government Information Quarterly, 37(3), 101486. https://doi.org/10.1016/j.giq.2020.101486

Atmojo, A. E. P., \& Nugroho, A. (2020). EFL classes must go online! Teaching activities and challenges during COVID-19 Pandemic in Indonesia. Register Journal, 13(1), 49-76.

Baazeem, R. (2020). How religion influences the use of social media: the impact of the online user's religiosity on perceived online privacy and the use of technology in Saudi Arabia [Doctoral dissertation, Kingston University]. https://eprints.kingston.ac.uk/id/eprint/47054/

Beshi, T. D., \& Kaur, R. (2020). Public trust in local government: Explaining the role of good governance practices. Public Organization Review, 20(2), 337-350. https://doi.org/10.1007/s11115-019-00444-6

Bhuiyan, S. H. (2011). Modernizing Bangladesh public administration through e-governance: Benefits and challenges. Government Information Quarterly, 28(1), 54-65. https://doi.org/10.1016/j.giq.2010.04.006

Bhuvana, M., \& Vasantha, S. (2020). Rural citizen satisfaction on e-health care services under egovernance service delivery model during Covid-19. International Journal of Management, 11(9), 554-565.

Bodrud-Doza, M., Shammi, M., Bahlman, L., Islam, A. R. M., \& Rahman, M. (2020). Psychosocial and socio-economic crisis in Bangladesh due to COVID-19 pandemic: A perception-based assessment. Frontiers in Public Health, 8. [Online].. https://doi.org/10.3389/fpubh.2020.00341

Conway, L. G., III, Woodard, S. R., \& Zubrod, A. (2020). Social psychological measurements of COVID-19: Coronavirus perceived threat, government response, impacts, and experiences questionnaires. https://doi.org/10.31234/osf.io/z2x9a

Crucke, S., \& Slabbinck, H. (2021). An experimental vignette study on the attractiveness of ownership-based carsharing communities: A social capital theory perspective. Environment and Behavior, 53(4), 379-408. https://doi.org/10.1177/0013916519888969

Dalle, J., Siyoto, S., Astika, N. D., Negara, D. J., Chandra, T., \& Anam, K. (2020). Moderating role of IT adoption and mechanism of dynamic capabilities on Indonesian pharmaceutical firms performance. Systematic Reviews in Pharmacy, 11(9), 982-992. https://doi.org/10.31838/srp.2020.9.142

DeFranza, D., Lindow, M., Harrison, K., Mishra, A., \& Mishra, H. (2020). Religion and reactance to COVID-19 mitigation guidelines. American Psychologist. [Advance online publication]. https://doi.org/10.1037/amp0000717

Evans, J. H., \& Hargittai, E. (2020). Who doesn't Trust Fauci? The public's belief in the expertise and shared values of scientists in the COVID-19 pandemic. Socius, 6, 1-13. https://doi.org/10.1177/2378023120947337 
Fetzer, T., Witte, M., Hensel, L., Jachimowicz, J., Haushofer, J., Ivchenko, A., Ivchenki, A., Caria, S., Reutskaja, E., Roth, C., Fiorin, S., Gomez, M., Kraft-Todd, G., Goetz, F. M., \& Yoeli, E. (2020, April). Global behaviors and perceptions in the COVID-19 pandemic. Harvard Business School Working 20-111. https://www.hbs.edu/faculty/Pages/item.aspx?num=58060

Gates, B. (2020). Responding to Covid-19-a once-in-a-century pandemic? New England Journal of Medicine, 382(18), 1677-1679. https://doi.org/10.1056/NEJMp2003762

Gultom, S., Dalle, J., Restu, Baharuddin, Hairudinoar, \& Gultom, S. (2020). The influence of attitude and subjective norm on citizen's intention to use e-government services. https://doi.org/10.9770/jssi.2020.9.m(14)

Hair, J. F., Black, W. C., Babin, B. J., \& Anderson, R. E. (2010). Multivariate data analysis - A global perspective (7th ed.). Pearson Prentice Hall.

Hale, T., Petherick, A., Phillips, T., \& Webster, S. (2020). Variation in government responses to COVID-19. Blavatnik School of Government Working Paper, 31. https://www.bsg.ox.ac.uk/sites/default/files/2021-06/BSG-WP-2020-032-v12_0.pdf

Henseler, J., Ringle, C. M., \& Sarstedt, M. (2015). A new criterion for assessing discriminant validity in variance-based structural equation modeling. Journal of the Academy of Marketing Science, 43(1), 115-135. https://doi.org/10.1007/s11747-014-0403-8

Henseler, J., Ringle, C. M., \& Sinkovics, R. R. (2009). The use of partial least squares path modeling in international marketing. In R. R. Sinkovics \& P. N. Ghauri, (Eds.), New challenges to international marketing (pp. 277-319). Emerald Group Publishing Limited.

Huber, S., \& Huber, O. W. (2012). The centrality of religiosity scale (CRS). Religions, 3(3), 710724. https://doi.org/10.3390/rel3030710

Islam, M. D., \& Siddika, A. (2020). COVID-19 and Bangladesh: A study of the public perception on the measures taken by the government. Heliyon, 6(7). e04399 [Online]. https://doi.org/10.1016/j.heliyon.2020.e04399

Khemani, S. (2020). An opportunity to build legitimacy and trust in public institutions in the time of COVID-19. World Bank. https://openknowledge. worldbank.org/handle/10986/33715

Kuru, A. T. (2009). Secularism and state policies toward religion: The United States, France, and Turkey: Cambridge University Press.

Liang, L.-L., Tseng, C.-H., Ho, H. J., \& Wu, C.-Y. (2020). Covid-19 mortality is negatively associated with test number and government effectiveness. Scientific Reports, 10(1), 1-7. https://doi.org/10.1038/s41598-020-68862-x

Luczak, C., \& Kalbag, A. (2018). The appropriateness and effectiveness of cross-aged peer mentoring in the learning environment. International Journal of Humanities, Arts and Social Sciences, 4(2), 76-84. https://doi.org/10.20469/ijhss.4.10003-2

Mansoor, M. (2021a). Citizens' trust in government as a function of good governance and government agency's provision of quality information on social media during COVID-19. Government Information Quarterly, 101597. https://doi.org/10.1016/j.giq.2021.101597

Mansoor, M. (2021b). An interaction effect of perceived government response on COVID-19 and government agency's use of ICT in building trust among citizens of Pakistan. Transforming Government: People, Process and Policy. Advance online publication. https://doi.org/10.1108/TG-01-2021-0002

Mansoor, M., \& Paul, J. (2021). Consumers' choice behavior: An interactive effect of expected eudaimonic well-being and green altruism. Business Strategy and the Environment, 1-16. https://doi.org/10.1002/bse.2876 
Mietzner, M. (2020). Populist anti-scientism, religious polarisation, and institutionalised corruption: How Indonesia's democratic decline shaped its COVID-19 response. Journal of Current Southeast Asian Affairs, 39(2), 227-249. https://doi.org/10.1177/1868103420935561

Mouritsen, P. (2006). The particular universalism of a Nordic civic nation: common values, state religion and Islam in Danish political culture: Per Mouritsen Multiculturalism, Muslims and citizenship (pp. 81-104). Routledge.

Mudwari, N., Beasy, K., Murphy, C., \& Cuskelly, M. (2021). Views of adolescent Bhutanese refugees on home learning during school shutdown across the period of COVID-19. Journal of Ethnic and Cultural Studies, 8(4), 286-306.

Myeong, S., Kwon, Y., \& Seo, H. (2014). Sustainable e-governance: The relationship among trust, digital divide, and e-government. Sustainability, 6(9), 6049-6069. https://doi.org/10.3390/su6096049

Noor, U., Mansoor, M., \& Rabbani, S. (2021). Brand hate and retaliation in Muslim consumers: does offensive advertising matter? Journal of Islamic Marketing. Advance online publication. https://doi.org/10.1108/JIMA-10-2020-0316

Obid, S. N. S., \& Naysary, B. (2016). Toward a comprehensive theoretical framework for Shariah governance in Islamic financial institutions. In T. Harrison \& E. Ibrahim (Eds.), Islamic Finance (pp. 10-31). Palgrave-MacMillian.

Olivia, S., Gibson, J., \& Nasrudin, R. (2020). Indonesia in the Time of Covid-19. Bulletin of Indonesian Economic $\quad$ Studies, $\quad 56(2), \quad 143-174$. https://doi.org/10.1080/00074918.2020.1798581

Pabbajah, M., Said, N. M., \& Faisal, M. (2020). Deauthorization of the religious leader role in countering Covid-19: Perceptions and responses of Muslim societies on the Ulama's policies in Indonesia. International Journal of Criminology and Sociology, 9(1), 263-273.

Paredes, M. R., Apaolaza, V., Fernandez-Robin, C., Hartmann, P., \& Yañez-Martinez, D. (2021). The impact of the COVID-19 pandemic on subjective mental well-being: The interplay of perceived threat, future anxiety and resilience. Personality and Individual Differences, 170, 110455. https://doi.org/10.1016/j.paid.2020.110455

Park, H., \& Blenkinsopp, J. (2011). The roles of transparency and trust in the relationship between corruption and citizen satisfaction. International Review of Administrative Sciences, 77(2), 254-274. https://doi.org/10.1177/0020852311399230

Purwanto, P., Kuswandi, K., \& Fatmah, F. (2020). Interactive applications with artificial intelligence: The role of trust among digital assistant users. Governance, 14(2), 64-75.

Rahiem, M., \& Rahim, H. (2020). The sultan and the soup: A Javanese cultural response to COVID-19. Journal of Ethnic and Cultural Studies, 8(1), 43-65.

Royo-Vela, M., \& McBee, K. A. (2020). Is IS online chatter just noise?: An analysis of the Islamic state strategic communications. International Journal of Strategic Communication, 14(3), 179-202. https://doi.org/10.1080/1553118X.2020.1770768

Ruswanti, E., Eff, A., \& Kusumawati, M. (2020). Word of mouth, trust, satisfaction and effect of repurchase intention to Batavia hospital in West Jakarta, Indonesia. Management Science Letters, 10(2), 265-270. doi: 10.5267/j.msl.2019.9.006

Sadeghi, S., Sajjadi, S. N., Nooshabadi, H. R., \& Farahani, M. J. (2018). Social-cultural barriers of Muslim women athletes: Case study of professional female athletes in Iran. Journal of Management Practices, Humanities and Social Sciences, 2, 6-10.

Sawatsuk, B., Darmawijaya, I. G., Ratchusanti, S., \& Phaokrueng, A. (2018). Factors determining the sustainable success of community-based tourism: Evidence of good corporate 
governance of Mae Kam Pong Homestay, Thailand. International Journal of Business and Economic Affairs, 3(1), 13-20. https://doi.org/10.24088/IJBEA-2018-31002

Sayogo, D. S. (2018). Online traceability for Halal product information: Perceptions of Muslim consumers in Indonesia. Journal of Islamic Marketing, 9(1), 99-116. https://doi.org/10.1108/JIMA-07-2016-0057

Seifert, C., \& Kwon, W.-S. (2019). SNS eWOM sentiment: impacts on brand value co-creation and trust. Marketing Intelligence \& Planning, 38(1), 89-102. 10.1108/mip-11-2018-0533

Shammi, M., Bodrud-Doza, M., Islam, A. R. M. T., \& Rahman, M. M. (2020). Strategic assessment of COVID-19 pandemic in Bangladesh: Comparative lockdown scenario analysis, public perception, and management for sustainability. Environment, Development Sustainability, 23, 6148-6191. https://doi.org/10.1007/s10668-020-00867-y

Shmueli, G., Sarstedt, M., Hair, J. F., Cheah, J.-H., Ting, H., Vaithilingam, S., \& Ringle, C. M. (2019). Predictive model assessment in PLS-SEM: Guidelines for using PLSpredict. European Journal of Marketing, 53(11) 2322-2347. https://doi.org/10.1108/EJM-02-20190189

Sikhangezile, N., \& Modise, M. A. (2020). Social distancing, cultural and psychological effects on learners in a rural setting in Zimbabwe. Journal of Ethnic and Cultural Studies, 7(3), 200209. https://doi.org/10.29333/ejecs/503

Starke, C., Marcinkowski, F., \& Wintterlin, F. (2020). Social networking sites, personalization, and trust in government: Empirical evidence for a mediation model. Social Media+ Society, 6(2). Advance online publication. https://doi.org/10.1177/2056305120913885

Sueca, I. N., Sumertha, I. N., \& Winaja, I. W. (2021). A time-lag study on perceived threat of COVID-19 in Hindu religious community: Moderating role of Hindu religious coping. Journal of Ethnic and Cultural Studies, 8(3), 217-243. https://doi.org/10.29333/ejecs/855

Susanto, R., Rachmadtullah, R., \& Rachbini, W. (2020). Technological and pedagogical models: Analysis of factors and measurement of learning outcomes in education. Journal of Ethnic and Cultural Studies, 7(2), 1-14. https://doi.org/10.29333/ejecs/311

Wasike, C. N. (2017). Financial regulation as moderating, influence of corporate governance, institutional quality, human capital and firm size on financial institutions performance in Kenya. Journal of Administrative and Business Studies, 3(6), 292-304. https://ssrn.com/abstract $=3744876$

Wirtz, B. W., Langer, P. F., Göttel, V., \& Thomas, M.-J. (2020). Public social media services: A citizen's perspective. Public Performance \& Management Review, 43(6), 1342-1358. https://doi.org/10.1080/15309576.2020.1760112

Wong, L. P., Alias, H., Wong, P.-F., Lee, H. Y., \& AbuBakar, S. (2020). The use of the health belief model to assess predictors of intent to receive the COVID-19 vaccine and willingness to pay. Human Vaccines Immunotherapeutics, 16(9), 2204-2214. https://doi.org/10.1080/21645515.2020.1790279

Yamamori, K. (2019). Classroom practices of low-cost STEM education using scratch. Journal of Advanced Research in Social Sciences and Humanities, 4(6), 192-198. https://doi.org/10.26500/JARSSH-04-2019-0601

Yasuda, S. (2020). The social significance of religious guides: The development of the flow of religious capital in the Islamic religious tourism industry. In G. Yildirim., O. Ozbek, C. C. Kilinc, \& A. A. Tarinc (Eds.), Cases on tour guide practices for alternative tourism (pp. 181-199). IGI Global. 


\section{Notes on Contributors}

Dadang Hartanto is currently a lecturer of department of public administration of Universitas Muhammadiyah Sumatera Utara. Beside a lecturer, He is also a member of police department of Republik Indonesia. He gained undergraduate degree (S.I.K) from Sekolah Tinggi Ilmu Kepolisian in 2002, and Master degree and Doctoral Degree both majoring in Public Administration and gained from Universitas Indonesia in 2005 and 2015. His research focus on public administratin and social sciences.

Agussani Agussani is currently a professor of department of social welfare of Universitas Muhammadiyah Sumatera Utara. Beside a Professor, He is also services as a Rector of Universitas Muhammadiyah Sumatera Utara since 2010 to present. He gained undergraduate degree (Drs) from Universitas Muhammadiyah Sumatera Utara in 1986, Master degree (M.AP) from Universitas Medan Area in 2004, and Doctoral Degree from Universitas Pendidikan Indonesia in 2013. His research focus on social welfare and social sciences.

Juhriyansyah Dalle is a lecturer at Department of InformationTechnology Universitas Lambung Mangkurat, Banjarmasin Indonesia. He gained his master's degree in computer sciences from Universitas Gadjah Mada in 2003, and Doctoral Degree from Universiti Utara Malaysia in 2010. His academic interest areas are Information studies, multimedia content, educational technology and media and area of expertise are human-computer interaction, and usability, computers in education, information system development, e-govermenance, and applied statistics in education and information technology. 